\title{
Epidemiology of Pennella sp. (Crustacea: Copepoda), in exploited Illex coindetii stock in the NE Atlantic*
}

\author{
S. PASCUAL ${ }^{1}$, A.F. GONZALEZ ${ }^{2}$, C. GESTAL ${ }^{1}$, E. ABOLLO ${ }^{1}$ and A. GUERRA ${ }^{2}$ \\ ${ }^{1}$ Lab. de Parasitología. Facultad de Ciencias del Mar. Universidad de Vigo. Apdo. 874-36200 Vigo. Spain. \\ E-mail: spascual@uvigo.es \\ ${ }^{2}$ Instituto de Investigaciones Marinas (CISC). Eduardo Cabello 6, 36208. Vigo. Spain.
}

\begin{abstract}
SUMMARY: The spatio-temporal distribution of the mesoparasitic copepod Pennella sp. on the short-finned squid Illex coindetii was studied monthly during 1993 in the southeastern North Atlantic (Galician waters, NW Spain). A total of 600 individuals were analysed separately considering two areas (north and west) with different hydrographical characteristics. Six pennellid stages were found: a copepodite, four chalimus stages and the free-living adult male and female. Epidemiology was assessed using the parasite demographic parameters. The results revealed a marked seasonal pattern in the number of parasites in squid samples from the northern area. This seasonal pattern was not detected in squids from the western area. The observed frequency distributions of parasites on the host population were aggregative at each sampling area. Infection values were extraordinarily high when they are compared with published host-parasite records for other representatives of the genus Pennella. Advantages of the parasite aggregation pattern and possible explanations of the seasonality variations in the number of parasites observed in squid samples from the northern area are discussed.
\end{abstract}

Key words: Pennella sp., ommastrephid squids, epidemiology.

\section{INTRODUCTION}

One of the primary tasks of squid fisheries ecologists is to emphasise how the innate characteristics of the squid population and its environment determine and constrain its productivity as a resource (Dobson and May, 1987). As a result of interactions, parasites may have a wide range of detrimental effects on exploited squid stocks, reducing host numbers due to mortality, fecundity, condition or market value (Kabata, 1981; Roubal, 1986; Khan, 1988). A general perception of fish macroparasites is that most of them seem to have little effect on the host, except in rare instances of massive infection (Dobson and May,

\footnotetext{
*Received December 29, 1999. Accepted March 14, 2001.
}

1987). This perception means the existence of a biological homeostatic equilibrium between the host and the parasite, so that a slight or medium infestation does not cause many problems for host populations. Estimates of "natural" loss of a particular stock may usually depend on the number of infective stages present within any individual host.

Most studies on wild fish populations focused on a taxonomical approach often address the existence of infestation of fish with parasitic copepods (Kabata, 1979). Comparatively little has been done on the taxonomy and ecology of parasitic copepods of cephalopods. Hochberg (1990) reviewed the siphonostomatoids, cyclopoids, harpacticoids and caligoids associated with cephalopods suggesting that most of the species do not cause a serious injury 
to the host. Although copepods are relatively abundant in several commercial squid groups, they are not considered a major cause of damage to squid stocks. Nevertheless, Pascual et al. (1997) indicated that parasitic infestations produced by Pennella sp. Oken, 1816 (Siphonostomatoida: Pennellidae) in short-finned squids (Illex coindetii Verany, 1839) affected the condition of those heavily-infected squids, reducing the productivity and the commercial value of the infested stock. In Galician waters, the economic loss for the fishery sector due to the infested ommastrephid stocks is estimated in about 0.6 million USD for the period 1980-1991 (Pascual et al., 1998).

Illex coindetii and Todaropsis eblanae are the most abundant ommastrephid squids off the Galician coast (north-western Spain). In Galicia, the annual catch from 1980 and 1998 ranged from 490 to 2,352 tonnes, experienced important monthly and interannual fluctuations with highest landing indices in spring and autumn. Catch of both species off the Galician coast represented $26 \%$ in weight and $14 \%$ in economic value with regard to the total cephalopod catch between 1980 and 1991. In Spain, both species represented $10 \%$ in weight and $4 \%$ in economic value of total cephalopod catches (González et al., 1996c). The average catch per year from 1980 to 1991 was about 1000 tonnes.

The main aim of this study was to examine the spatio-temporal distribution of the siphonostomatoid genus Pennella within the population of Illex coindetii, providing information on the population dynamics of the etiological agent.

\section{MATERIAL AND METHODS}

The separation of two sampling areas was undertaken considering differences in hydrographic conditions existing in the north and west areas of the Galician waters (Fraga, 1981; Fraga et al., 1982). Summer meteorological conditions are favourable for upwelling of nutrient-rich water in the west area, where a water mass of the south-flowing North Atlantic Central Water (ENACW) is seasonally upwelled (Rocha et al., 1999). This event could imply the possibility of the existence of two different ommastrephid stocks.

Monthly samples of Illex coindetii were obtained from commercial landings in Burela and Celeiro (north coast of Galicia) and Ribeira (west coast of Galicia) (Fig. 1). A total of 25 squid per sampling

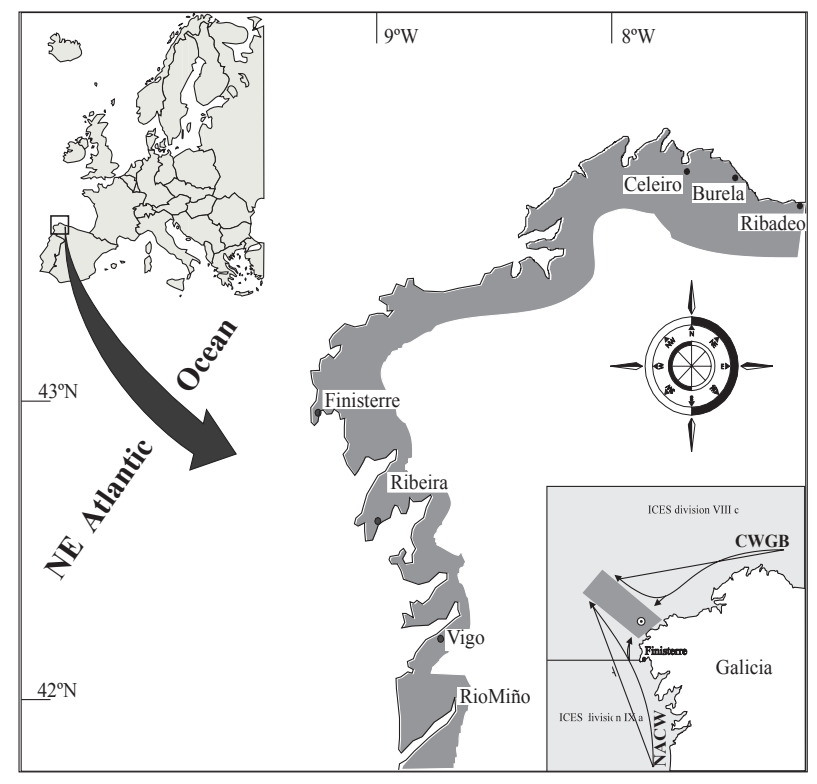

FIG. 1. - Location of the sampling area showing trawl stations along the NW Spanish Coast. Scheme of surface circulation of central water between 100 and $400 \mathrm{~m}$ depth is also included. The shaded area is the zone of lateral contact between the NACW (North Atlantic Central Water) and the CWGB (Central Water of the Gulf of Biscay).

area were collected monthly and examined during 1993. Mantle length of the specimens ranged from 78 and $360 \mathrm{~mm}$. Samples were obtained from both otter and pair trawlers where squids were taken as by-catch in the fishery targeting hake and blue whiting.

Squid samples were separated in two groups according to the area where they were caught. The northern group comprised all squids collected from Ribadeo to Finisterre and the western group was formed by squids caught from Finisterre to Miño river (Fig. 1).

Parasitic larvae, found either free inside the mantle cavity or fixed to the gill lamellae of the squid, were counted and removed from the host under a stereomicroscope for identification of parasite larval stages. Parasites were fixed in $70 \%$ ethanol, cleared with lactic acid and stained with chlorazole black E from three to five hours depending on the concentration of the stain. The appendages of each developmental stage were examined by light microscopy using the "wooden slide" method (Humes and Gooding, 1964).

The terms prevalence, mean intensity and abundance were used according to Bush et al. (1997). Prevalence $(P)$ : number of individuals of a host species infected with a particular parasite species divided by the number of hosts examined; Mean intensity $(I)$ : total number of individuals of a partic- 
ular parasite species in a sample of a host species divided by the number of infected individuals of the host species in a sample; Abundance $(A)$ : total number of individuals of a particular parasite species in a sample of hosts divided by the total number of individuals of the host species (infected plus uninfected) in the sample. The nature of parasite distribution within host populations was determined by estimating the variance/mean ratio ( $\beta$, Dispersion Index) (Anderson and Gordon, 1982). Seasonal differences in the number of copepod parasites were also analysed using the Lowest Significant differences ANOVA test which denotes pairs of groups significantly different at the 0.05 level: winter being January-March (group 1); spring, April-June (group 2); summer, July-September (group 3); and autumn, October-December (group 4). Data normality were verified by using Kolmogorov-Smirnov test and when this premise failed, the data were log-transformed $(n+1)$ to reduce the variance and normalise the data (Elliot, 1979). The data were processed using the SPSS-PC (+) 6.1.3. statistical software.

\section{RESULTS}

A series of developmental stages of the lernaeoceriform larvae was found either free inside the mantle cavity (the copepodid and adult forms) or fixed to the gill lamellae (chalimus larvae) of the squid. The six pennellid stages were free-swimming copepodid, four parasitic chalimus stages sessile on the host, a
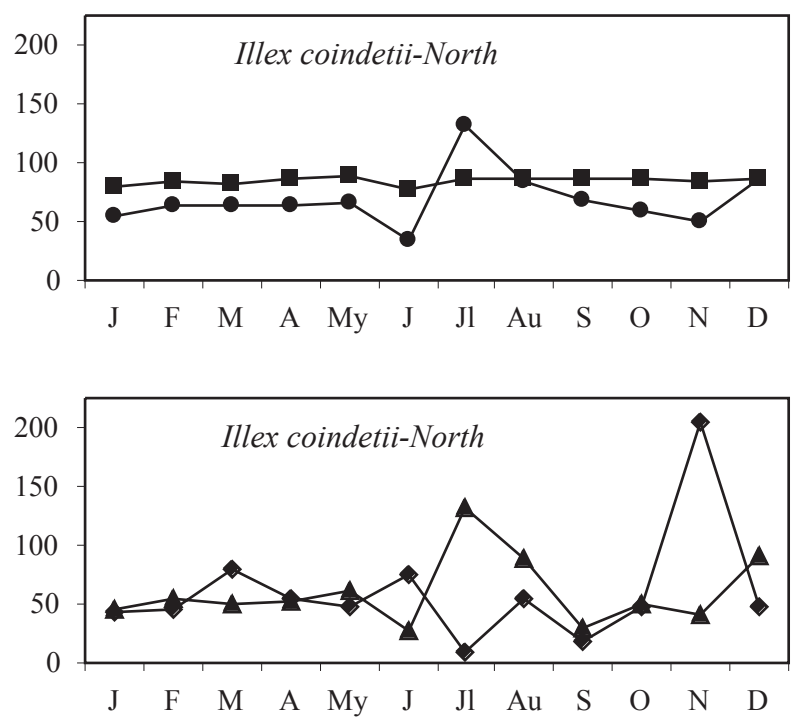

free-swimming adult male and a free-swimming immature post-mated adult female. Parasitic larvae within each individual gill filament were abundant in the most anterior lamellae (distant to the branchial heart). Almost all larvae (98.6\%) were situated between secondary lamellae with their posterior end directed towards the efferent filament artery.

\section{Population dynamics}

Infestation values were extraordinarily high at both sampling areas, with prevalence levels $(P)$ ranging from $80 \%$ to $100 \%$ in the north area and 30 to $100 \%$ in the west area (Fig. 2). Mean intensity (I) ranged from 33 to 140 in the north area, and 1 to 80 in the western area. The mean number of parasites per host examined $(A)$ varied from 35 to 140 in the north area and from 1 to 80 in the west area. In the north area, abundance of infestation was slightly higher than in the west area $(\mathrm{F}=5.559 ; p<0.05)$.

The copepod distribution within the squid population was systematically aggregative (over-dispersed or clumped). Variance to mean ratios of the parasites were greater than 1.0 at each month over the whole sampling area (Fig. 2). The dispersion index, $B$, was higher in the north area $(\mathrm{F}=13.706$; $p<0.05)$ than in the west area.

LSD-ANOVA test did not reveal seasonal significant differences in the north area $(\mathrm{F}=1.180 ; p>0.05)$ which implies the absence of two seasonal patterns in the number of parasites. However, a clear seasonal pattern in the number of parasitic copepods
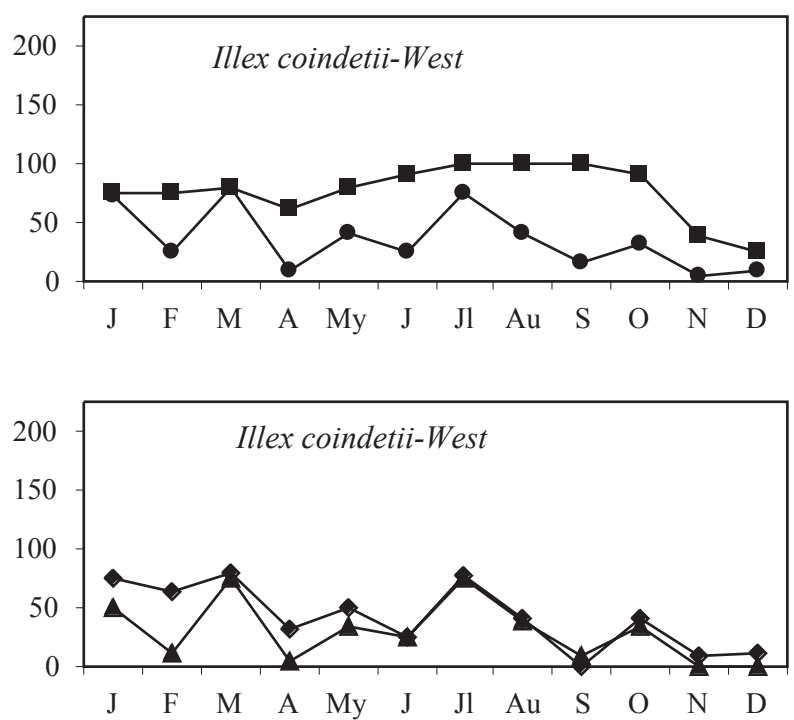

FIG. 2. - Monthly values in the prevalence (P), mean intensity (I), abundance (A) and dispersion index (DI) of Pennella sp. on the ommastrephid $I$. coindetii in the south-eastern North Atlantic (Galician waters). $\mathrm{n}=$ Prevalence $(\%)$; $\mathrm{s}=$ Abundance; $\mathrm{l}=\mathrm{Mean}$ intensity; $\mathrm{u}=$ Dispersion index. 
TABLE 1. - Analysis of seasonal patterns in the number of copepod parasites by lowest significant differences (ANOVA Test). * denotes pairs of groups with significant differences at $p<0.05$. Winter, January-March (group 1); spring, April-June (group 2); summer, JulySeptember (group 3); autumn, October-December (group 4).

\begin{tabular}{llcccc}
\hline Mean & Group & Group 1 & Group 2 & Group 3 & Group 4 \\
\hline 1.0810 & Group 1 & & & $*$ & $*$ \\
0.9486 & Group 2 & & $*$ & $*$ & $*$ \\
1.2865 & Group 3 & $*$ & $*$ & $*$ \\
0.1943 & Group 4 & & & \\
\hline
\end{tabular}

$(\mathrm{F}=21.756 ; p<0.05)$ was found in the west area (Table 1, Fig. 2). Squids collected in winter and spring had more post-embryonic stages of Pennella sp. than those squids collected during the summer. Both pairs of groups (group1-2 and group 3) were also significantly different in relation to the squids sampled in autumn (group 4).

\section{DISCUSSION}

\section{Aggregation}

The aggregated distribution of parasites in Illex coindetii may represent an evolutionary strategy as a direct consequence of the two-host life cycle of the parasitic female. Like most species of the copepod family Pennellidae, the female life cycle of Pennella includes two hosts, with the egg-producing female usually situated in the gill cavity of gadids (Kabata, 1979). The life cycle of this parasitic copepod consists of two pelagic nauplius stages and a copepodite stage. The copepodite infects the intermediate host, usually a flatfish (Kabata, 1979) and/or a cephalopod (Pascual et al., 1996b) species, and moults into a chalimus larva that is sessile on the gill tips of the host. After four successive chalimus stages, the parasite matures (Anstensrud, 1990a). Copulation between an adult free-moving male and a mature sessile female takes place on the intermediate host (Anstensrud, 1990b). Both virgin and non-virgin females leave the intermediate host, usually within one week after maturation, and are thus available for copulation only during a short time (Anstensrud, 1989). After a brief free-swimming period, the post-chalimus female infects a final host (usually a gadid), where the main post-larval growth takes place. Because of their change of host, pennellid females probably have a higher post-mating mortality and are available for inseminating during a shorter time than females with only one host in the life cycle.
Macroparasites have been found almost invariably aggregated in their distribution among host individuals within a host population (Anderson and Gordon, 1982). Such aggregated distributions are of considerable ecological importance. Thus, given a mean number of parasites per host, aggregated distributions increase the level of mean crowding (Lloyd, 1967) experienced by the average number of parasites. Therefore, there is an increase in the intensity of density-dependent factors regulating the parasite population (Keymer, 1982). It can be assumed that density-dependent factors are of little importance for determining the infection level of pennellid species in the intermediate hosts. It was found by several authors that the number of parasites per intermediate host individual can accumulate to seemingly unconstrained numbers: $630 \mathrm{Ler}$ naeocera branchialis in 1 flounder; 26,700 L. branchialis in 1 lumpfish; or more than 800 Pennella sp. in 1 Illex coindetii (Templeman et al., 1976; Kabata, 1979; Van Damme, 1993; present study, respectively).

Another important consequence of aggregation is that, for parasites that mate within their hosts, aggregated distributions increase the probability of mating and diminish the probability that a parasite population die as a result of females failing to find males (May, 1983). Poulin and FitGerald (1989) pointed out that the tendency of crustacean parasites to attack and attach selectively to previously infected host explains the aggregated distribution of parasites, although the exact reasons for such hosts selection by the parasite are unclear.

Chemoreception (i.e., the parasite may secret a substance attracting conspecifics and favouring mate location) is thought to play an important role in host selection in copepod parasites (Kabata, 1981). However, Fryer (1965) suggested that small organisms are probably incapable of detecting such weak chemical gradients in water, except, perhaps, in cases where the host harbours a large number of parasites, their effects being cumulative. The aggre- 
gated pattern could, therefore, reduce the risks of parasite-caused death of the squids, providing the completion of the parasite life cycle in the final host.

\section{Infestation values}

It is difficult to elucidate which factors contributed to the slightly higher infestation levels in the north area when they are compared with those found in the west area. It is likely that the observed differences are due to more intense seasonal upwelling cycles in the west area (Varela, 1992) which may have produce an unbalanced host (Rasero, 1994) and parasite recruitment success. A slight decrease of the parasite infrapopulation that occurred during autumn is likely due to failure in parasite infestation, which corresponds with less-parasitised immature squids born in early summer after a prolonged spawning ranging from March to July (Gonzalez and Guerra 1996a, González et al., 1996b; Pascual, 1996).

Parasite infestation is a function of biotic factors linked to host characteristics and also to environment. Seasonal variations of parasitic copepods could be attributed to temperature variation and host population structure (Sousa and Gosholz, 1991). Concerning the population structure, the continuous inshore-offshore migrations of both ommastrephid species in the sampling area (Pascual et al., 1996a) could also contribute to the observed seasonal patterns of infection by Pennella sp.

\section{ACKNOWLEDGEMENTS}

We thank Dr. J.-S. Ho (California State University, Long Beach, California) and Dr. P. López (Universidad de Sevilla, Spain) for their generous help and valuable suggestions that improved the research. Thanks are also due to Ministerio de Educación y Ciencia for providing financial support under Project CICYT-MAR 95-1919-C05-03.

\section{REFERENCES}

Anderson, R.M. and D.M. Gordon. - 1982. Processes influencing the distribution of parasite numbers within host populations with special emphasis on parasite-induced host mortalities. Parasitology, 85: 373-398.

Anstensrud, M. - 1989. Experimental studies of the reproductive behaviour of the parasitic copepod Lernaeocera branchialis (Pennellidae). J. Mar. Biol. Assoc. UK., 69: 465-476.

Anstensrud, M. - 1990a. Mate guarding and mate choice in two copepods, Lernaocera branchialis (L.) (Pennellidae) and Lepeophtheirus pectoralis (Muller) (Caligidae), parasitic on flounder. J. Crust. Biol., 12: 31-40.
Anstensrud, M. - 1990b. Mating strategies of two parasitic copepods (Lernaeocera branchialis (L.)) (Pennellidae) and Lepeophtheirus pectoralis (Muller) (Caligidae) on flounder: polygamy, sex-specific age at maturity and sex ratio. J. Exp. Mar. Biol. Ecol., 136: 141-158.

Bush, A.O., K.D. Lafferty, J. Lotz and A.W. Shostak. - 1997. Parasitology meets ecology on its own terms: Margolis et al. revised. J. Parasitol., 83: 575-583.

Dobson, A.P. and R.M. May. - 1987. The effects of parasites on fish populations-Theoretical aspects. Int. J. Parasitol., 17: 363-370.

Elliot, J.M. - 1979. Some methods for the statistical analysis of benthic invertebrates. Freshwater Biological Association Science Publications No 25.

Fraga, F. - 1981. Upwelling off the Galician coast, northwest Spain. In: F.A. Richards (ed.), Coastal upwelling. Washington, DC, American Geographical Union: 176-182.

Fraga, F., C. Mouriño, and M. Manríquez. - 1982. Las masas de agua en las costas de Galicia: junio-octubre. Resultados de Expediciones Científicas, 10: 51-77.

Fryer, G. - 1965. Habitat selection and gregarious behaviour in parasitic crustaceans. Crustaceana, 10: 199-209.

González, A.F. and A. Guerra. - 1996a. Age and growth of the short-finned squid Illex coindetii (Cephalopoda, Ommastrephidae) off Galician waters (NW Spain) based on statolith analysis. ICES J. Mar. Sci, 53: 802-810.

González, A.F., B.G. Castro and A. Guerra. - 1996b. Reproductive biology of the short-finned squid Illex coindetii (Cephalopoda, Ommastrephidae) of the Northeastern Atlantic. Sarsia, 81: 107-118.

González, A.F., M. Rasero and A. Guerra. - 1996c. La explotación de los omastréfidos Illex coindetii y Todaropsis eblanae (Mollusca, Cephalopoda) en aguas de Galicia. Nova Acta Científica Compostelana (Bioloxía), 6: 191-203.

Hochberg, F.G. - 1990. Diseases of Mollusca: Cephalopoda. In: O. Kinne (ed.), Diseases of marine animals, Vol. III. Cephalopoda to Urochordata. Biologische Anstalt Helgoland: 47-227.

Humes, A.G. and R.V. Gooding. - 1964. A method for studying the external anatomy of copepods. Crustaceana, 6: 238-240.

Kabata, Z. - 1979. Parasitic Copepoda of British fishes. Royal Society, London, England. 468 pp.

Kabata, Z. - 1981. Copepoda (Crustacea) parasitic on fishes: problems and perspectives. Adv. Parasit., 19: 1-71.

Keymer, A. - 1982. Density-dependent mechanisms in the regulation of intestinal helminth populations. Parasitology, 84: 573-587.

Khan, R.A. - 1988. Experimental transmission, development, and effects of a parasitic copepod, Lernaeocera branchialis, on Atlantic cod, Gadus morhua. J. Parasitol., 586-599.

Lloyd, M. - 1967. Mean crowding. J. Anim. Ecol., 36: 1-30.

May, R.M. - 1983. Parasitic infections as regulators of animal populations. Am. Sci., 71: 36-45.

Pascual, S. - 1996. Los sistemas hospedador-parásito en la pesquería de omastréfidos de Galicia. Tesis Doctoral, Universidad de Vigo, 167 pp.

Pascual, S., C. Gestal and E. Abollo. - 1997. Effect of Pennella sp. (Copepoda, Pennellidae) on the condition of Illex coindetii and Todaropsis eblanae (Cephalopoda, Ommastrephidae). Bull. Europ. Assoc. Fish Pathol., 17 (3/4): 91-95.

Pascual, S., A.F. González, and A. Guerra. - 1998. Effect of parasitism on the productivity of the ommastrephid stock in Galician waters: economic loss. Iberus, 16: 95-98

Pascual, S., C. Gestal, E. Abollo, H. Rodríguez, M. Soto, J. Estévez and C. Arias. - 1996a. Anisakis simplex B (Nematoda, Anisakidae), a parasite tag indicating the population biology and movements of northeast Atlantic short-finned squids. IV International Symposium Cephalopods. Present and Past. Granada, 139.

Pascual, S., C. Gestal, J. Estévez, H. Rodríguez, M. Soto, E. Abollo and C. Arias. - 1996b. Parasites in commercially-exploited cephalopods (Mollusca, Cephalopoda) in Spain: an updated perspective. Aquaculture, 142: 1-10.

Poulin, R. and G.J. FitGerald. - 1989. A possible explanation for the aggregated distribution of Argulus canadensis Wilson, 1916 (Crustacea: Branchiura) on juvenile sticklebacks (Gasterosteidae). J. Parasitol., 75: 58-60.

Rasero, M. - 1994. Relationship between cephalopod abundance and upwelling: the case of Todaropsis eblanae (Cephalopoda: Ommastrephidae) in Galician waters (NW Spain). Int. Comm. Explor. Sea. C. M. 1994/ K:20. 
Rocha, F., A. Guerra, R. Prego and U. Piatkowski. - 1999. Cephalopod paralarvae and upwelling conditions off Galician waters (NW Spain). J. Plankton. Res., 21: 21-33.

Roubal, F. R. - 1986. The histopathology of the copepod, Ergasilus lizae Kroyer, on the pseudobranchs of the teleost, Acanthopagnus australis (Gunther), in northern New South Wales. J. Fish Dis., 9: 213-223.

Sousa, W. P. and E.D. Grosholz. - 1991. The influence of habitat structure on the transmission of parasites. In: S. Bell, E. McCoy and $\mathrm{H}$. Mushinsky (eds.), Habitat structure: the physical arrangement of objects in space. Chapman and Hall, London: 301-324.

Templeman, W., V.M. Hudder and A.M. Fleming. - 1976. Infection of lumpfish (Cyclopterus lumpus) with larvae and of Atlantic cod (Gadus morhua) with adults of the copepod, Lernaeocera branchialis, in and adjacent to the Newfoundland area, and inferences therefrom on inshore-offshore migrations of cod. $J$. Fish Res. Board Can., 33: 711-731.

Van Damme, P.A. - 1993. The suprapopulation dynamics of the marine fish parasites Lernaeocera lusci and Lernaeocera branchialis (Copepoda, Pennellidae). Ph.D. Thesis. Univ. Leuven.

Varela, M. - 1992. Upwelling and phytoplankton ecology in Galician (NW Spain) rias and shelf waters. Bol. Inst. Esp. Oceanogr., 8(1): 57-74.

Scient. ed.: P. Abelló 